
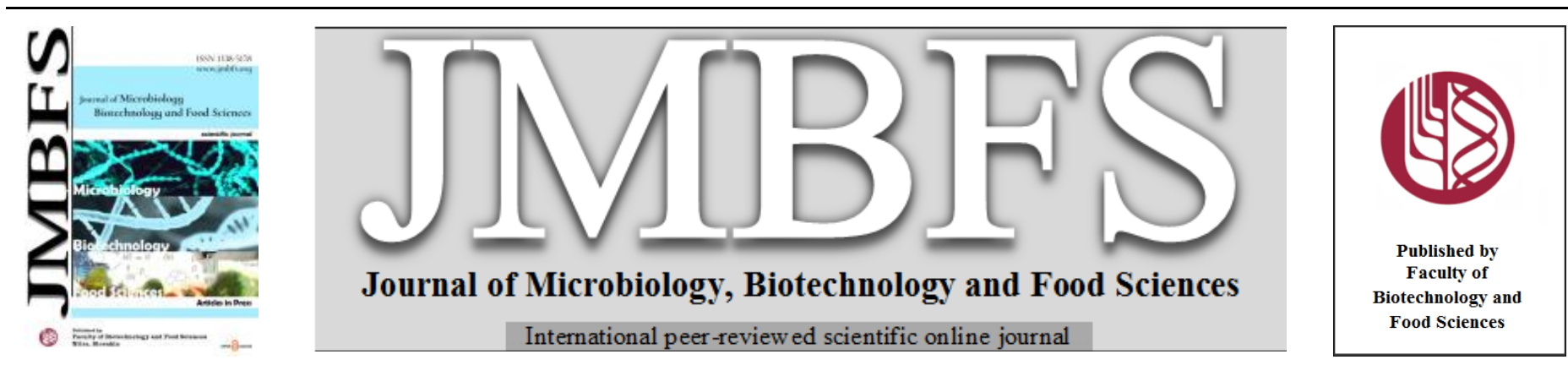

\title{
QUALITATIVE AND QUANTITATIVE ENZYMATIC PROFILE OF NATIVE Trichoderma STRAINS AND BIOCONTROL POTENTIAL AGAINST Fusarium oxysporum f.sp. cubense RACE 1
}

\author{
Dulce Jazmín Hernández-Melchor ${ }^{1}$, Ronald Ferrera-Cerrato ${ }^{1}$, Pablo A. López-Pérez ${ }^{2}$, Mariana R. Ferrera-Rodríguez ${ }^{1}$, Clemente de \\ Jesús García-Ávila ${ }^{3}$, Alejandro Alarcón ${ }^{* 1}$
}

$\operatorname{Address(es):~}$

${ }^{1}$ Colegio de Postgraduados, Posgrado de Edafología, Microbiología de Suelos. Carretera México-Texcoco km 36.5, Montecillo 56230, Estado de México, México.

${ }^{2}$ Universidad Autónoma del Estado de Hidalgo, Escuela Superior Apan, Carretera Apan-Calpulalpan Km.8, Col. Chimalpa, 43920 Apan, Hidalgo.

${ }^{3}$ Centro Nacional de Referencia Fitosanitaria. Dirección General de Sanidad Vegetal, Servicio Nacional de Sanidad, Inocuidad y Calidad Agroalimentaria

(SENASICA). Unidad de Integral de Servicios de Diagnóstico y Constatación. Carretera Federal México-Pachuca km 37.5, Tecámac 55740 Estado de México. México.

*Corresponding author: aalarconcp@gmail.com

https://doi.org/10.55251/jmbfs.3264

\section{ARTICLE INFO}

Received 13. 6. 2021

Revised 23. 9. 2021

Accepted 24. 9. 2021

Published 1. 2. 2022

Regular article OPEN OACCESS

\section{ABSTRACT}

Trichoderma is a ubiquitous fungal genus in the rhizosphere, often utilized as biofertilizer and biocontrol agent that may release enzymes involved in the control of certain fungal phytopathogens. This research evaluated the biotechnological potential of fifteen native Trichoderma strains that were previously isolated from the rhizosphere of maize cultivated at the Estado de Mexico (Mexico). The radial growth rate of each fungal strain was assessed as well as the qualitative analysis of enzyme activity on specific culture media. Then, eight prominent strains were selected for evaluating their capability of degrading four complex substrates (filter paper, newspaper, starch, and chitin), and their antagonism towards five isolates of Fusarium oxysporum f.sp. cubense Race 1 (FocR1). Eight out of the fifteen Trichoderma strains showed high radial growth rate $(0.137-0.149 \mathrm{~cm} / \mathrm{h})$, and good qualitative enzyme activities (cellulase, pectinase, and chitinase) when compared to a positive control strain T. reesei CDBB-H-356. The best eight strains (EMV6SIC2, EMV6SIC4, EMV6SIC5, EMV6SIC6, EMV6SIC7, EMV6SIC8, EMMVrSIC4, and EMMVSIC2) showed good inhibition to the five FocR1 isolates (ranging from 3 to 54\%), and good capability for degrading cellulosic substrates (filter paper and newspaper) via production of active enzymes. Data were analyzed by one way analysis of variance (ANOVA), followed by a multiple comparison test (Tukey, $\alpha=0.05$ ). In conclusion, some native Trichoderma strains have good biotechnological potential for being directed to the industry since they produce cellulases; at the same time, these fungal strains may release chitinases by which fungi may control and degrade the cell wall of FocR1 isolates.

Keywords: biocontrol, Trichoderma, Fusarium, cellulase, pectinase, chitinase

\section{INTRODUCTION}

Trichoderma is a cosmopolite fungus widely studied due to its agroecological potential, high adaptation to extreme environments, and production of metabolites (enzymes, plant growth promoting compounds, volatile compounds, among others) for biotechnological and environmental purposes (Sharma et al. 2017; Sharma and Sharma, 2020). Trichoderma species produce certain enzymes that are able to degrade solid organic residues, by which they may significantly contribute on both mineralization and recycling of industrial residues (Idris et al., 2017; Marques et $\boldsymbol{a l . , 2 0 1 7 ) . ~ T h e ~ l a t e r ~ a l s o ~ g e n e r a t e s ~}$ byproducts with added values such as enzymes, sugars, biofuels, among others (Behera et al., 2017; Hernández-Melchor et al., 2019).

Trichoderma reesei is one of the most utilized species for industrial purposes since it produces cellulose-degrading enzymes, but the cost of culture media may represent a limitation for these biotechnological processes (Fang and Xia, 2015). Thus, for this enzyme production, several substrates like lignin-rich residues have been utilized like wheat straw, sugarcane bagasse, used paper sludge's, newspaper residues, and wood residues (Guoweia et al., 2011; Bohacz and Korniłlowicz-Kowalska, 2020) by using fermentative systems with solid substrates or submerged cultures (Kumar et al., 2014; Ajijolakewu et al., 2017). Furthermore, endoglucanases, exoglucanases, and $\beta$-glucosidases are the most relevant enzymes for cellulose degradation, which require specific conditions of $\mathrm{pH}$ and temperature; therefore, several biotechnological strategies have been designed like submerged batch culture in reactors for optimizing the process, and reducing operational costs (Fenila and Shastri, 2016; Weiss et al., 2020).

In addition, Trichoderma species are directed for biocontrolling fungal phytophatogens due to several mechanisms of action such as antibiosis, mycoparatisism, competition of space and nutrients, and production of secondary metabolites (Argumedo-Delira et al., 2009; Bunbury-Blanchette and Walker, 2019; De la Cruz-Quiroz et al., 2018). During mycoparasitism, Trichoderma releases enzymes like proteases, chitinases and glucanases that cause the hydrolysis of target fungal cell walls (Gruber and Seidl-Seiboth, 2012, Harman et al., 2012; García-Espejo et al., 2016; Silva et al., 2019). Thus, several species of Trichoderma have been directed for the biocontrol of soilborne fungi that cause diseases in important agricultural crops like tomato, rice, maize, banana, and avocado, among others (Diánez et al., 2016; Kiriga et al. 2018). Therefore, Trichoderma is one of the most effective and successful biocontrol agent for agriculture, and some species are part of more than $60 \%$ of the biofungicide formulations already registered worldwide (Charoenrak and Chamswarng, 2016; Gorai et al., 2020).

The utilization of Trichoderma strains in agriculture and biotechnology has increased, but the isolation and the identification of new and promising species are still needed, as well as the characterization and evaluation of biological effectiveness of fungal-derived metabolites. Due to the effectiveness of this fungal genus under several environments, it is relevant to study the enzyme profile of native Trichoderma strains as potential agents of biocontrol. In addition, the evaluation of the capability of Trichoderma species for producing specific enzymes is desirable, especially when fungi are applied in submerged cultures in which agro-industrial residues are utilized as a carbon source. Thus, this study evaluated the biotechnological potential of native Trichoderma strains previously isolated from maize rhizosphere, and their antagonism towards Fusarium oxysporum f.sp. cubense Race 1 (FocR1). 


\section{MATERIAL AND METHODS}

\section{Fungal strains}

The growth of fifteen strains of Trichoderma were reactivated; these strains were previously isolated from maize roots and rhizosphere soil at two plant phenology stages [vegetative growth (V6 stage) and maturity] collected from Estado de Mexico, Mexico (Herrera-Jiménez et al., 2018), obtained from a previous Research Grant RHIZOMAIZ. Fungal preservation was performed in test tubes with potato dextrose agar (PDA Baker ${ }^{\circledR}$ ) and in cryopreservation vials with $1 \mathrm{~mL}$ of $0.01 \%$ Tween 20 solution (Herrera-Jiménez et al., 2018). In addition, the strain of Trichoderma ressei CDBB-H-356 donated by the National Collection of Microbial Strains and Cellular Cultures (Instituto Politecnico Nacional) registered at the WFCC (World Federation for Culture Collection) was utilized as positive control for enzyme bioassays.

Five strains of Fusarium oxysporum f.sp. cubense Race 1 (FocR1) were utilized These banana phytopathogens were obtained from the Mycology Laboratory of the Centro Nacional de Referencia Fitosanitaria (CNRF) belonged to the Servicio Nacional de Sanidad, Inocuidad y Calidad Agroalimentaria (SENASICA Mexico). These fungal phytopathogens are identified as CNRF-MIC17188, CNRF-MIC17189, CNRF-MIC17190, CNRF-MIC17191, and CNRFMIC17192.

Both fungal genera Trichoderma and FocR1 were propagated on Petri dishes containing PDA, and incubated at $28{ }^{\circ} \mathrm{C}$ for 5 days. Afterwards, Trichoderma cultures were exposed to light conditions at room temperature for two days to induce sporulation.

\section{DNA extraction, PCR amplification and molecular identification of Trichoderma strains}

The genomic DNA from the 15 Trichoderma strains was extracted from mycelium samples by using three solutions: 1) $10 \mathrm{mM}$ TRIS, $60 \mathrm{mM} \mathrm{NaCl}, 5 \%$ Sucrose, and $10 \mathrm{mM}$ EDTA; 2) $300 \mathrm{mM}$ Tris, $1.25 \%$ SDS, 5\% Sucrose, and 10 mM EDTA; and 3) 3M Potassium acetate. The quality and quantity of DNA was determined by gel electrophoresis in a 1\% agarose gel, and nanodrop (BioSpecNano, Shimazdu $\left.{ }^{\circledR}\right)$, respectively. The universal primers ITS1 (forward) and ITS4 (reverse) were used for amplifying the ITS rDNA region. The PCR reaction was performed as suggested in the protocol of the kit Taq PCR Master Mix adjusting the mix reaction to $25 \mu \mathrm{L}$. The amplifying conditions included a denaturing stage at $94{ }^{\circ} \mathrm{C}$ and 30 cycles at $94{ }^{\circ} \mathrm{C}$ for $45 \mathrm{~s}$, and alignment at $51{ }^{\circ} \mathrm{C}$ and $72{ }^{\circ} \mathrm{C}$ for 45 $\mathrm{s}$. The PCR products were verified by gel electrophoresis in $1 \%$ agarose gel and subsequently, sequenced by means of the Sanger method performed at the Laboratorio de Servicios Genómicos (LANGEBIO, CINVESTAV).

All sequences were edited with the program Codon Code Aligner (CodonCode Corporation, www.codoncode.com) and aligned in MEGA (Kumar et al., 2016) Furthermore, sequences were analyzed with the BLAST program (Basic Local Alignment Search Tool). Later, after the sequence edition, fragments of $416 \mathrm{bp}$ were obtained and compared at the GenBank database, and registered. The GenBank access code for fungal strains were included in Table 1.

\section{Determination of the radial growth rate of Trichoderma strains}

The radial growth rate of all Trichoderma strains was estimated on PDA medium in Petri dishes ( $8.5 \mathrm{~cm}$ diameter). A $3 \mathrm{~mm}$-disk of PDA with active growth of the each fungus was set by triplicate at the center of the Petri dish, and incubated a $28^{\circ} \mathrm{C}$. The fungal radial growth rate was measured every $24 \mathrm{~h}$ until fungi reach the border of the Petri dishes (García-Espejo et al., 2016).

Qualitative analysis of cellulase, chitinase and pectinase enzymes on culture media

All qualitative analysis of enzymes were carried out in Petri dishes $(8.5 \mathrm{~cm}$ of diameter). The cellulase activity was determined on culture medium containing 5 $\mathrm{mL}$ of the Winogradsky saline solution $\left[5 \mathrm{~g} / \mathrm{L} \mathrm{K}_{2} \mathrm{HPO}_{4}, 2.5 \mathrm{~g} / \mathrm{L} \mathrm{MgSO}_{4}, 2.5 \mathrm{~g} / \mathrm{L}\right.$ $\left.\mathrm{NaCl}, 0.5 \mathrm{~g} / \mathrm{L} \mathrm{Fe}\left(\mathrm{SO}_{4}\right)_{3}\right], 1 \mathrm{~g} \mathrm{NH}_{4} \mathrm{NO}_{3}$, and $1 \mathrm{~mL}$ of micronutrient solution $(0.05$ $\mathrm{g} / \mathrm{L} \mathrm{KMoO}{ }_{4}, 0.05 \mathrm{~g} / \mathrm{L} \mathrm{MnSO}_{4}, 0.05 \mathrm{~g} / \mathrm{L} \mathrm{Na}_{3} \mathrm{BO}_{3}, 0.05 \mathrm{~g} / \mathrm{L} \mathrm{CoNO}_{3}, 0.05 \mathrm{~g} / \mathrm{L}$ $\mathrm{CdSO}_{4}$, and $0.05 \mathrm{~g} / \mathrm{L} \mathrm{Cu}_{2} \mathrm{SO}_{4}$ ), pH 6.5 (Winogradsky, 1950), in which $10 \mathrm{~g}$ de carboxymethylcellulose was added (Ordoñez-Valencia, 2014). The culture medium was poured in Petri dishes, and a $3 \mathrm{~mm}$ agar-disk with the corresponding fungal growth was set at the center of each plate by triplicate. Fungal cultures were incubated at $28^{\circ} \mathrm{C}$ for 4 days. The halo of cellulose hydrolysis was detected by adding $15 \mathrm{~mL}$ of Congo red solution (1\%) for $15 \mathrm{~min}$, and then decanted for further application of $15 \mathrm{~mL}$ of $1 \mathrm{M} \mathrm{NaCl}$ solution for $15 \mathrm{~min}$; then, the hydrolysis halo was measured.

The chitinase activity was determined by preparing $10 \mathrm{~g}$ of colloidal chitin (Sigma ${ }^{\circledR}, \mathrm{C}-9213$ ) mixed with $100 \mathrm{~mL}$ of $85 \%$ phosphoric acid. This mix was kept at $4{ }^{\circ} \mathrm{C}$ for $24 \mathrm{~h}$, and occasionally stirred. Therefore, the chitin was precipitated with an excess of distilled water, and filtered throughout two layers of cheese cloth, and washed until reaching a neutral $\mathrm{pH}$. The filtrate was sterilized at $121{ }^{\circ} \mathrm{C}$ for $18 \mathrm{~min}$, and kept at $4^{\circ} \mathrm{C}$ until further utilization (Romero-
Cortes et al., 2016). To determine the positive chitinase reaction, a modified basal medium (BM) consisted on $0.3 \mathrm{~g} / \mathrm{L} \mathrm{MgSO}_{4} \cdot 7 \mathrm{H}_{2} \mathrm{O}, 3.0 \mathrm{~g} / \mathrm{L}\left(\mathrm{NH}_{4}\right)_{2} \mathrm{SO}_{4}, 2.0$ $\mathrm{g} / \mathrm{L} \mathrm{KH}_{2} \mathrm{PO}_{4}, 1.0 \mathrm{~g} / \mathrm{L}$ monohydrated citric acid, $30 \mathrm{~g} / \mathrm{L}$ agar, $4.5 \mathrm{~g} / \mathrm{L}$ of colloidal chitin, and $0.15 \mathrm{~g} / \mathrm{L}$ bromocresol purple. The $\mathrm{pH}$ was adjusted to 2.8 with the sodium acetate buffer sterilized at $121{ }^{\circ} \mathrm{C}$ for $18 \mathrm{~min}$ (García-Espejo et al., 2016). Petri dishes were inoculated with a $3 \mathrm{~mm}$ agar disk with active growth of the corresponding fungus by triplicate, and incubated at $28{ }^{\circ} \mathrm{C}$ until a change of color from bright yellow to intense violet was observed (García-Espejo et al., 2016).

The determination of pectinase activity was performed by using the culture medium proposed by Hankin et al. (1971), and consisted on preparing two solutions. Solution A consisted on $2 \mathrm{~g} / \mathrm{L}$ yeast extract, $10 \mathrm{~g} / \mathrm{L}$ apple or orange pectin and $30 \mathrm{~g} / \mathrm{L}$ agar. Solution B included $2 \mathrm{~g} / \mathrm{L}\left(\mathrm{NH}_{4}\right)_{2} \mathrm{SO}_{4}, 4 \mathrm{~g} / \mathrm{L} \mathrm{KH}_{2} \mathrm{PO}_{4}, 6$ $\mathrm{g} / \mathrm{L} \mathrm{Na}_{2} \mathrm{HPO}_{4}, 0.1 \mathrm{mg} / \mathrm{L} \mathrm{FeSO}{ }_{4} \cdot 7 \mathrm{H}_{2} \mathrm{O}, 1 \mathrm{mg} / \mathrm{L} \mathrm{CaCl}_{2}, 10 \mu \mathrm{g} / \mathrm{L} \mathrm{H}_{3} \mathrm{BO}_{3}, 70 \mu \mathrm{g} / \mathrm{L}$ $\mathrm{MnSO}_{4}, 50 \mu \mathrm{g} / \mathrm{L} \mathrm{CuSO}_{4}, 10 \mu \mathrm{g} / \mathrm{L} \mathrm{MoO}_{3}$, with a $\mathrm{pH}$ of either 7 or 5 . Two equal volumes of both solutions were mixed and sterilized at $121{ }^{\circ} \mathrm{C}$ for $18 \mathrm{~min}$, and the culture medium was poured in Petri dishes. The Trichoderma inoculation was performed as previously described, and plates were incubated at $28{ }^{\circ} \mathrm{C}$ for 3 days Therefore, the Petri dishes were added with lugol for $5 \mathrm{~min}$, and this solution was decanted for observing the corresponding clear halo denoting pectinase activity. In this assay, two types of pectinase activity were detected: the pectatelyase activity (pectate transeliminase E.C.4.2.2.2) at $\mathrm{pH} \mathrm{7,} \mathrm{and} \mathrm{the} \mathrm{polygalacturonase}$ activity (endo-polygalacturonase E.C. 3.2.1.15) at $\mathrm{pH}$ 5. Pectatelyase is usually characterized under alkaline $\mathrm{pH}$, whereas polygalacturonase is detected in acid $\mathrm{pH}$ values. By adjusting the $\mathrm{pH}$ values in culture medium it was possible to differentiate between lyase and polygalacturonase activity (Hankin et al. 1971).

\section{Quantitative analysis of enzyme activities by using four substrates}

The degradation kinetics of four substrates [filter paper, newspaper, starch, and chitin (Sigma ()$)$ ] were determined by growing the Trichoderma strains in a submerged culture for 14 days at $30^{\circ} \mathrm{C}$, and $200 \mathrm{rpm}$. Each test was carried out by triplicate with the corresponding substrate and with the fungal strain. For this, $50 \mathrm{~mL}-F a l c o n$ tubes were utilized; each tube contained $35 \mathrm{~mL}$ of basal minimum medium (BMM) [6 g/L Na $2 \mathrm{HPO}_{4}, 3 \mathrm{~g} / \mathrm{L} \mathrm{KH}_{2} \mathrm{PO}_{4}, 2.64 \mathrm{~g} / \mathrm{L}\left(\mathrm{NH}_{4}\right)_{2} \mathrm{SO}_{4}, 0.5 \mathrm{~g} / \mathrm{L}$ $\left.\mathrm{MgSO}_{4} \cdot 7 \mathrm{H}_{2} \mathrm{O}, 0.015 \mathrm{~g} / \mathrm{L} \mathrm{CaCl}_{2}, 3 \mathrm{~g} / \mathrm{L} \mathrm{MnSO}_{4}, 3 \mathrm{~g} / \mathrm{L} \mathrm{ZnSO}_{4}\right]$, with a $\mathrm{pH} 4.8$, adjusted with a $0.05 \mathrm{M}$ citrate buffer (García-Espejo et al., 2016). Afterwards, the respective substrate to be degraded was added: $1 \% \mathrm{w} / \mathrm{v}$ of starch, $1 \% \mathrm{w} / \mathrm{v}$ of chitin, one strip $(1 \mathrm{x} 11 \mathrm{~cm})$ of filter paper, and one strip $(1 \mathrm{x} 11 \mathrm{~cm})$ of newspaper. Each tube was inoculated with a spore suspension $\left(1 \times 10^{6}\right.$ spores $\left./ \mathrm{mL}\right)$ of the corresponding fungal strain. In addition, test tubes with the corresponding substrates without fungal inoculum were set as blanks (controls). Every three days during 14 days, $1.5 \mathrm{~mL}$ aliquots were taken for determining the corresponding enzyme activities that are described as follows.

The total cellulase activity was evaluated by means of the bioassay with filter paper (FPase), and with the endoglucanase activity (CMCase) performed by the DNS technique (Miller, 1959; Ghose, 1987), and by using D-Glucose as blank For the FPase, a blank test tube and one problem tube were used. Both tubes were added with $1 \mathrm{~mL}$ of citrate buffer $\mathrm{pH} 4.8$, one strip of filter paper Whatman No.1 $(1 \times 6 \mathrm{~cm})$, and incubated for $5 \mathrm{~min}$ at $50{ }^{\circ} \mathrm{C}$. Then, an aliquot of $0.5 \mathrm{~mL}$ of the supernatant of the corresponding fungal culture was added only for the problem tube. Tubes were incubated for $60 \mathrm{~min}$ at $50{ }^{\circ} \mathrm{C}$, and subsequently were set at room temperature, and $2 \mathrm{~mL}$ of DNS solution were added. At the end, $0.5 \mathrm{~mL}$ of the supernatant of fungal culture was added to the blank tube. Thus, tubes were incubated at $90{ }^{\circ} \mathrm{C}$ for $5 \mathrm{~min}$, and cooled in iced water.

For estimating the CMCase activity, two tubes were also utilized (blank tube and problem tube). Both tubes were added with $0.5 \mathrm{~mL}$ of a $2 \%$ de carboxymethyl cellulose (CMC) solution in a $0.05 \mathrm{M}$ sodium citrate buffer, $\mathrm{pH} 4.8$, and incubated for $5 \mathrm{~min}$ at $50{ }^{\circ} \mathrm{C}$. Afterwards, a $0.5 \mathrm{~mL}$ of the supernatant of the fungal culture was only added to the problem tubes. The tubes were incubated for $30 \mathrm{~min}$ at $50{ }^{\circ} \mathrm{C}$, and subsequently set at room temperature, and added with $2 \mathrm{~mL}$ of the DNS solution. At the end, $0.5 \mathrm{~mL}$ of the fungal supernatant was added to the blank tube. Tubes were incubated at $90{ }^{\circ} \mathrm{C}$ for $5 \mathrm{~min}$, and cooled with iced water.

The chitinase activity was performed by means of the method described by Vargas-Hoyos and Gilchrist-Ramelli (2015). The production of sugars was determined with the method of Miller (1959) using N-acetyl-D-glucosamine (GlcNAc) as blank. For the enzyme quantification, two tubes were also utilized (blank tube and problem tube). Both tubes were added with $0.1 \mathrm{~mL}$ of $0.25 \%$ colloidal chitin solution in a $0.05 \mathrm{M}$ sodium citrate buffer, $\mathrm{pH} 4.8$, and incubated for $5 \mathrm{~min}$ at $40{ }^{\circ} \mathrm{C}$. Afterwards, a $0.05 \mathrm{~mL}$ of the supernatant of the fungal culture was only added to the problem tube. The tubes were incubated for $30 \mathrm{~min}$ at 40 ${ }^{\circ} \mathrm{C}$, and subsequently set at room temperature, and added with $3 \mathrm{~mL}$ of the DNS solution. At the end, $0.05 \mathrm{~mL}$ of the fungal supernatant was added to the blank tube. Tubes were incubated at $90{ }^{\circ} \mathrm{C}$ for $5 \mathrm{~min}$, and cooled with iced water.

For the three enzymatic activities from each tube, corresponding aliquots of 250 $\mu \mathrm{L}$ were taken and placed in 96-well clear microplates (Costar $\left.{ }^{\circledR}\right)$ to measure absorbance readings at $540 \mathrm{~nm}$ with a microplate reader (Synergy 2, Biotek ${ }^{\circledR}$ ). Each unit of enzyme activity was defined as the amount of the enzyme required to release $1 \mu \mathrm{mol} / \mathrm{min}$ of the reducing sugar, and expressed as equivalents of 
glucose under our experimental conditions. The enzyme activities were expressed in terms of international units per liter (IU/L). Each enzyme assay was performed by triplicate.

\section{Biocontrol assays of Trichoderma strains against five strains of FocR1}

The biocontrol evaluation was based on performing bioassays of confrontation of eight selected Trichoderma strains against five isolates of FocR1. These bioassays considered the utilization of dual cultures in which a $3 \mathrm{~mm}$-agar disk of active growth of the respective FocR 1 strain was set in one extreme of the Petri dish containing PDA, incubated at $28{ }^{\circ} \mathrm{C}$ for $24 \mathrm{~h}$. Afterwards, a $3 \mathrm{~mm}$-agar disk with active growth of the respective Trichoderma strain (five replicates) was set in the opposite extreme of the Petri dish; plates were incubated at $28{ }^{\circ} \mathrm{C}$ until fungal confrontation was completed. The growth of both fungi was evaluated every $24 \mathrm{~h}$. In addition, three replicates of either antagonist (Trichoderma strain) or pathogen (FocR1 strain) were set as controls. The inhibition percentage of the growth of FocR1 due to each Trichoderma strain was estimated by using the method proposed by Vargas-Hoyos and Gilchrist-Ramelli (2015).

\section{Statistical analysis}

Analysis of variance (ANOVA) and the multiple mean comparison test (Tukey, $\mathrm{P} \leq 0.05$ ) were used to assess significant differences among parameters like the capability of degrading four complex substrates (filter paper, newspaper, starch and chitin), and the antagonism of eight Trichoderma strains against five isolates of Fusarium oxysporum f.sp cubense Race 1. As complement of this analysis, it was proposed to use a descriptive tool for examining and displaying patterns in multivariate data called "Radial plot". This type of graph is practical and profoundly useful for a wide variety of data. The common feature of radial plots is that they are a circular graphing method and have a series of rays projecting from a central point to different variables. The analyses were processed using the Origin Pro 8.0 statistical software and SigmaPlot ${ }^{\circledR}$ software 14.0 (Saary, 2008; Orea et al., 2017; Porter and Niksiar, 2018; López Pérez et al., 2020).

\section{RESULTS AND DISCUSSION}

Taxonomic identification of Trichoderma strains

The fifteen Trichoderma strains were labeled as EMV6SIC1, EMV6SIC2, EMV6SIC4, EMV6SIC5, EMV6SIC6, EMV6SIC7, EMV6SIC8, EMMVrSIC2, EMMVrSIC4, EMMVS2C3, EMMVSIC2, EMMVrSIC3, EMMVS3C1, EMMVrS2C3, and EMMVS2C1. Table 1 shows the taxonomic identification of each fungal strain achieved from phylogenetic analysis. Thirteen of these strains corresponded to T. harzianum, and the two remaining strains (EMMVSIC2 and EMMVS2C1) were identified as T. tomentosum and $T$. gamsii, respectively.

Besides having a good potential for biocontrolling fungal phytopathogens for crops (for instance, cocoa, tomato, potato) (Torres-De la Cruz et al., 2015; AlHazmi and TariqJaveed, 2016; Contina et al., 2017), T. harzianum has a biotechnological importance due to the production of important enzymes for industrial purposes like cellulases (Libardi et al., 2017; de Souza et al., 2018), lacases (Ranimol et al., 2018), xylanases (Lopez-Ramirez et al., 2018), among others. Similarly, T. tomentosum is able to degrade Azo colorants (He et al., 2018) and polycyclic aromatic hydrocarbons (Marchand $\boldsymbol{e t}$ al., 2017), whereas, T. gamsii produces volatile organic compounds related to the biocontrol (Chen et al., 2016; Galletti et al., 2020), and growth inhibition of $F$. oxysporum f. sp. cepae (Bunbury-Blanchette and Walker, 2019).

\section{Radial growth rate and qualitative enzyme activity}

Table 1 shows the radial growth rate of the Trichoderma strains, which ranged from 0.091 to $0.150 \mathrm{~cm} / \mathrm{h}$. The fast growing strains were EMV6SIC2, EMV6SIC5, EMV6SIC6, EMV6SIC7, EMV6SIC8, EMMVrSIC4, EMMVSIC2, and EMMVrSIC3. The radial growth rates of these fungal strains were 1.1 fold higher than that obtained for T. reesei CDBB-H-356 $(0.137 \mathrm{~cm} / \mathrm{h})$.

The $T$. reesei strain was used as referential fungus due to its high enzyme production (Li et al., 2019; Weiss et al., 2020), and for comparing the qualitative enzyme activity determined for the Trichoderma strains. All Trichoderma strains had positive qualitative detection of cellulase, chitinase and pectinase (pectatelyase and polygalacturonase) activities. Table 1 shows the diameter of halos which ranged from $2.7-6.2 \mathrm{~cm}, 3.3-7.2 \mathrm{~cm}$, and 3.9-7.4 for cellulase pectatelyase and polygalacturonase activities, respectively. All values were higher than those detected for the referential Trichoderma strain $(3.2 \mathrm{~cm}$ of cellulose, 3.3 . cm of pectatelyase, and $3.9 \mathrm{~cm}$ of polygalacturonase). In addition, a $100 \%$ of chitin degradation (detected by color changes) was observed in shorter time (4-6 days) than $T$. reesei (11 days).

From results of the radial growth rate and the qualitative enzyme detection, eight strains were selected (EMV6SIC2, EMV6SIC4, EMV6SIC5, EMV6SIC6, EMV6SIC7, EMV6SIC8, EMMVrSIC4, and EMMVSIC2) whose radial growth rate ranged from 0.142 to $0.149 \mathrm{~cm} / \mathrm{h}$. In addition, these fungal strains showed greater halos of cellulase and pectinase hydrolysis than those observed for the referential strain ( $T$. reesei CDBB-H-356), as well as less time for chitin degradation. The later indicates that our Trichoderma strains release important enzymes that may degrade complex organic substrates.

Table 1 Radial growth rate and qualitative enzyme activities for 15 Trichoderma strains isolated from maize roots cultivated in the Estado de Mexico

\begin{tabular}{|c|c|c|c|c|c|c|c|}
\hline $\begin{array}{c}\text { Keys of Trichoderma } \\
\text { isolates }\end{array}$ & $\begin{array}{c}\text { Fungal } \\
\text { identification }\end{array}$ & $\begin{array}{c}\text { GenBank } \\
\text { access } \\
\text { codes }\end{array}$ & $\begin{array}{c}\text { Radial } \\
\text { growth } \\
\text { rate } \\
(\mathrm{cm} / \mathrm{h})\end{array}$ & $\begin{array}{l}\text { Cellulase } \\
\text { Halo } \\
\text { diameter } \\
(\mathbf{c m})\end{array}$ & $\begin{array}{c}\text { Chitinase } \\
100 \% \text { color } \\
\text { change }\end{array}$ & $\begin{array}{c}\text { Pectatolyase } \\
\text { activity pH } 7 \\
\text { Halo diameter } \\
(\mathrm{cm})\end{array}$ & $\begin{array}{c}\text { Polygalacturonase } \\
\text { activity pH } 5 \\
\text { Halo diameter } \\
\text { (cm) }\end{array}$ \\
\hline EMV6SIC2 & T. harzianum* & MK652840 & 0.144 & $4.9 \pm 0.2$ & Day 5 & $4.9 \pm 0.1$ & $3.9 \pm 0.8$ \\
\hline EMV6SIC4 & T. harzianum* & MK652843 & 0.137 & $5.7 \pm 0.1$ & Day 5 & $4.8 \pm 0.1$ & $5.6 \pm 0.1$ \\
\hline EMV6SIC5 & T. harzianum* & MK652837 & 0.143 & $5.4 \pm 0.5$ & Day 5 & $7.2 \pm 0.2$ & $6 \pm 0.9$ \\
\hline EMV6SIC6 & T. harzianum* & MK652836 & 0.149 & $5.7 \pm 0.6$ & Day 5 & $4.2 \pm 0.6$ & $5.9 \pm 0.1$ \\
\hline EMV6SIC7 & T. harzianum* & МТ920962 & 0.142 & $5.2 \pm 0.1$ & Day 5 & $4.5 \pm 0.1$ & $6.2 \pm 0.6$ \\
\hline EMV6SIC8 & T. harzianum* & MK652833 & 0.147 & $5.1 \pm 0.1$ & Day 4 & $5 \pm 0.6$ & $6.2 \pm 0.3$ \\
\hline EMMVrSIC4 & T. harzianum* & MK652847 & 0.148 & $4.4 \pm 1.7$ & Day 4 & $6.4 \pm 1.3$ & $5.5 \pm 0.3$ \\
\hline EMMVSIC2 & T. tomentosum* & MK652832 & 0.147 & $4.4 \pm 0.6$ & Day 4 & $3.3 \pm 0.3$ & $5.4 \pm 0.3$ \\
\hline EMV6SIC1 & T. harzianum & MK652836 & 0.135 & $4.5 \pm 0.9$ & Day 5 & $5 \pm 0.1$ & $5.2 \pm 0.03$ \\
\hline EMMVrSIC2 & T. harzianum & MK652848 & 0.104 & $2.7 \pm 0.1$ & Day 5 & $4.5 \pm 1.1$ & $5.1 \pm 0.5$ \\
\hline EMMVS2C3 & T. harzianum & MK652834 & 0.132 & $6.2 \pm 0.1$ & Day 5 & $4.5 \pm 0.04$ & $5.8 \pm 0.2$ \\
\hline EMMVrSIC3 & T. harzianum & MK652834 & 0.15 & $4.8 \pm 0.1$ & Day 4 & $5.6 \pm 0.03$ & $7.4 \pm 0.5$ \\
\hline EMMVS3C1 & T. harzianum & MK652841 & 0.126 & $4.6 \pm 0.5$ & Day 4 & $6.2 \pm 0.8$ & $6.9 \pm 0.5$ \\
\hline EMMVrS2C3 & T. harzianum & MK652851 & 0.091 & $5.3 \pm 0.4$ & Day 5 & $5.2 \pm 0.1$ & $5.4 \pm 0.3$ \\
\hline EMMVS2C1 & T. gamsii & MK652850 & 0.125 & $5.8 \pm 0.1$ & Day 6 & $5.7 \pm 1.9$ & $6 \pm 0.1$ \\
\hline T. reesei CDBB-H-356 & & & 0.137 & $3.2 \pm 0.04$ & Day 11 & $3.3 \pm 0.1$ & $3.9 \pm 0.2$ \\
\hline
\end{tabular}

Quantification of the enzyme activity on complex substrates in submerged cultures

Table 2 shows the results of the quantified enzymatic activities (FPase, CMCase and chitinase) of the selected eight Trichoderma strains as well as of the reference strain $T$. reesei $\mathrm{CDBB}-\mathrm{H}-356$ after 14 days, using newspaper, filter paper, starch and chitin as carbon sources. Thus, the mean comparison test showed significant differences $(\mathrm{P} \leq 0.05)$ among fungal treatments for each carbon source (Table 2) 
Table 2 Quantitative enzyme activity for eight strains of Trichoderma after 14 days, previously selected due to their qualitative enzyme activity and radial growth rate (See Table 1).

\begin{tabular}{|c|c|c|c|}
\hline \multirow{2}{*}{$\begin{array}{l}\text { Trichoderma strains/ } \\
\text { Substrate }\end{array}$} & \multicolumn{3}{|c|}{ Substrate-induced enzyme activity } \\
\hline & $\begin{array}{l}\text { Cellulase activity on filter paper (FPase) } \\
\text { (IU/L) }\end{array}$ & $\begin{array}{l}\text { Carboxymethyl cellulase (CMCase) } \\
\text { (IU/L) }\end{array}$ & $\begin{array}{l}\text { Chitinase activity } \\
\text { (IU/L) }\end{array}$ \\
\hline \multicolumn{4}{|l|}{ Newspaper } \\
\hline EMV6SIC4 & $996.4 \mathrm{~d} \pm 134.4$ & $7061.3 b c \pm 306.5$ & $513.7 \mathrm{c} \pm 136.0$ \\
\hline emv6sic5 & $887.3 \mathrm{~cd} \pm 65.1$ & $14788.6 \mathrm{~d} \pm 453.2$ & $575.4 \mathrm{~cd} \pm 145.7$ \\
\hline EMV6SIC6 & $922.3 \mathrm{~cd} \pm 30.9$ & $9271.7 \mathrm{c} \pm 319.9$ & $322.9 \mathrm{bc} \pm 56.7$ \\
\hline EMMVrSIC4 & $372.9 \mathrm{a} \pm 61.8$ & $1678.9 \mathrm{ab} \pm 321.5$ & $280.9 b \pm 11.9$ \\
\hline EMMVSIC2 & $696.3 \mathrm{~b} \pm 99.2$ & $8529.5 \mathrm{~cd} \pm 205.5$ & $306.1 \mathrm{ab} \pm 26.7$ \\
\hline Trichoderma reesei CDBB-H-356 & $774.3 \mathrm{bc} \pm 52.7$ & $7612.4 \mathrm{~cd} \pm 432.2$ & $216.4 \mathrm{a} \pm 35.0$ \\
\hline \multicolumn{4}{|l|}{ Filter paper } \\
\hline EMV6SIC2 & $879.5 \mathrm{a} \pm 157.8$ & $6249.8 \mathrm{a} \pm 360.7$ & $306.1 \mathrm{~b} \pm 46.5$ \\
\hline EMV6SIC4 & $934.0 \mathrm{ab} \pm 223$ & $11784.9 \mathrm{bc} \pm 401.0$ & $552.9 \mathrm{~d} \pm 68.0$ \\
\hline EMMVrSIC4 & $832.7 \mathrm{a} \pm 167.1$ & $19015.6 \mathrm{cb} \pm 179.8$ & $328.6 \mathrm{bc} \pm 19.4$ \\
\hline EMMVSIC2 & $1428.9 \mathrm{c} \pm 214.2$ & $28656.5 \mathrm{de} \pm 89.9$ & $345.4 \mathrm{bc} \pm 35.0$ \\
\hline Trichoderma reesei CDBB-H-356 & $1206.8 \mathrm{bc} \pm 67.4$ & $22188.9 \mathrm{~d} \pm 369.5$ & $306.1 \mathrm{~b} \pm 38.8$ \\
\hline \multicolumn{4}{|l|}{ Chitin (Sigma $\left.{ }^{\circledR}\right)$} \\
\hline EMV6SIC2 & $493.7 \mathrm{ab} \pm 140.5$ & $789.8 \mathrm{a} \pm 82.1$ & $547.3 \mathrm{c} \pm 48.6$ \\
\hline EMV6SIC4 & $1144.4 \mathrm{~b} \pm 362.8$ & $1573.1 \mathrm{~d} \pm 82.1$ & $710.1 \mathrm{~d} \pm 146.7$ \\
\hline EMV6SIC5 & $1117.2 \mathrm{~b} \pm 347.1$ & $1327.6 \mathrm{c} \pm 313.9$ & $833.5 \mathrm{de} \pm 59.1$ \\
\hline EMV6SIC6 & $1510.7 \mathrm{~cd} \pm 115.7$ & $1413.3 \mathrm{~cd} \pm 132.2$ & $850.3 \mathrm{e} \pm 179.9$ \\
\hline EMV6SIC7 & $1584.8 \mathrm{~d} \pm 115.7$ & $1480.8 \mathrm{~cd} \pm 421.5$ & $457.6 \mathrm{bc} \pm 71.4$ \\
\hline EMV6SIC8 & $1193.7 b \pm 167$ & $895.1 \mathrm{~b} \pm 270.1$ & $432.4 \mathrm{~b} \pm 59.5$ \\
\hline EMMVrSIC4 & $376.8 \mathrm{a} \pm 8.26$ & $844.4 \mathrm{ab} \pm 247.9$ & $356.6 \mathrm{ab} \pm 95.2$ \\
\hline EMV6SIC8 & $1416.1 \mathrm{bc} \pm 479.4$ & $1378.5 \mathrm{~b} \pm 198.4$ & $322.9 \mathrm{a} \pm 37.6$ \\
\hline EMMVrSIC4 & $1880.9 \mathrm{~d} \pm 278.3$ & $1348.0 \mathrm{~b} \pm 192.7$ & $552.9 \mathrm{~b} \pm 134.9$ \\
\hline EMMVSIC2 & $1586.0 \mathrm{~cd} \pm 384.6$ & $715.8 \mathrm{a} \pm 57.8$ & $474.4 \mathrm{ab} \pm 23.8$ \\
\hline Trichoderma reesei CDBB-H-356 & $1311.9 \mathrm{~b} \pm 252.2$ & $3554.9 \mathrm{e} \pm 220.6$ & $536.1 \mathrm{bc} \pm 71.4$ \\
\hline
\end{tabular}

*Mean values ( \pm standard errors) in a column followed by different letters for fungal treatment at each complex substrate, are significantly different (Tukey; $\mathrm{p} \leq 0.05$ ).

Figure 1 shows a radar plot that depicts the results of enzyme activities (cellulase and chitinase) achieved from the eight Trichoderma strains and the referential strain, for degrading four complex substrates (filter paper, newspaper, starch, and chitin). Graphs denote particular patterns of enzymatic activity on the four substrates at different scales, by which the following order was estimated: Carboxymethyl cellulase (CMCase) $>$ Cellulase activity on filter paper (FPase) $>$ Chitinase activity (Figure 1).

Table 3 Inhibition percentages of eight Trichoderma strains on the growth of five strains of Fusarium oxysporum f.sp. cubense Race 1.

\begin{tabular}{lccccc}
\hline \multirow{2}{*}{$\begin{array}{l}\text { Trichoderma } \text { strains } \text { / Fusarium } \\
\text { oxysorum strains }\end{array}$} & \multicolumn{5}{c}{ Fungal growth inhibition (\%) } \\
\cline { 2 - 6 } EMMVrSIC4 & CNRF-MIC17191 & CNRF-MIC17189 & CNRF-MIC17192 & CNRF-MIC17188 & CNRF-MIC17190 \\
EMMVSIC2 & 14.2 & 6.9 & 3.4 & 18.8 & 39.4 \\
EMV6SIC2 & 16.4 & 3.7 & $33.9^{*}$ & $53.0^{*}$ & 8.6 \\
EMV6SIC4 & 11.4 & 16.1 & 15.6 & 23.7 & 5.1 \\
EMV6SIC7 & 18.1 & 15.4 & 2.4 & 30.2 & 24.0 \\
EMV6SIC8 & 7.4 & 19.1 & 20.0 & 33.0 & 4.0 \\
EMV6SIC5 & 16.4 & 15.1 & 10.8 & 3.3 & 4.6 \\
EMV6SIC6 & $20.0^{*}$ & $22.6^{*}$ & 19.3 & 36.1 & $52.2^{*}$ \\
Trichoderma reesei CDBB-H-356 & 11.9 & 12.7 & 4.0 & 24.4 & 27.7 \\
Asterisks denote the highest growth inhibition achieved for each strain of FocR1. $\mathrm{n}=3$. & & 24.3 & 25.4 & 54.4 \\
\hline
\end{tabular}

Enzyme activities showed variations depending on sampling time, fungal strain, and target substrate (Figure 2). At $14^{\text {th }}$ day (Table 2), the highest values for
CMCase were achieved for the strain EMV6SIC5 in which the enzyme activities were as follows: $29692.1 \mathrm{IU} / \mathrm{L}$ on filter paper, and $14788.6 \mathrm{IU} / \mathrm{L}$ with newspaper; 
whereas the highest values of CMCase produced by the strain EMV6SIC7 was achieved when starch was added (2262.5 IU/L), and for the strain EMV6SIC4 occurred when chitin was used as substrate (1573.1 IU/L). In the same time, the highest values of FPase were presented for different strains. No significant differences were observed for FPase activities among strains EMV6SIC4, EMV6SIC5, EMV6SIC7 and EMMVrSIC4 whose values were 996.4, 1608.1, 1584.8 and $1880.9 \mathrm{IU} / \mathrm{L}$ in the presence of newspaper, filter paper, chitin and starch, respectively.

In regards chitinase activity, at $14^{\text {th }}$ day, the highest value was $620.3 \mathrm{IU} / \mathrm{L}$ for the strain EMV6SIC2 in the presence of newspaper. The strains EMV6SIC5 and EMV6SIC6 showed values of chitinases of $771.8 \mathrm{IU} / \mathrm{L}$ and $850.3 \mathrm{IU} / \mathrm{L}$, respectively, when either starch or chitin was added in the submerged culture Moreover, the strain EMV6SIC4 had high chitinase values (552.9 IU/L) when filter paper was applied to the submerged culture (Table 2).

The values of CMCase obtained in the present study were 20 to 200 times higher than those reported by García-Espejo $\boldsymbol{e t}$ al. (2016) who utilized carboxymethylcellulose as a carbon source for T. inhamatum BOL12QD grown in agitation and stationary conditions. Conversely, the chitinase activity detected for our Trichoderma strains was 200 times lower than those values reported by Ting and Chai (2015) with T. harzianum in presence of colloidal chitin, in which the achieved enzyme activity was of $354970 \mathrm{IU} / \mathrm{L}$.

The FPase activity depended on the carbon source (filter paper, newspaper, chitin or starch) and on the Trichoderma strain. Thus, the FPase activity was simila $(1608 \mathrm{IU} / \mathrm{L})$ or 1.5 times higher (1880 IU/L) than those values reported by de Souza et al. (2018) who demonstrated similar FPase for T. harzianum (1630 $\mathrm{IU} / \mathrm{L}$ ) when either cellulose or lactose was used as carbon source. In this regard, our results differed from values reported in the literature, but the nature and complexity of the substrate significantly influence on the induction of the enzyme production of certain fungal species (Gelain et al., 2015; Li et al., 2019; Bohacz and Kornillowicz-Kowalska, 2020). In the same manner, some cultural conditions of bioreactors like temperature, stirring, $\mathrm{pH}$, and others, may also affect both production and effectiveness of fungal-derived enzymes (Delabona $\boldsymbol{e} t$ al., 2012; Gutiérrez-Rojas et al., 2015; Adnan et al., 2019).

The cellulase and chitinase activities detected for Trichoderma strains acting on the four substrates, denote the capability of degrading polysaccharides rich in glucose and N-acetyl-D-glucose-2-amine derived from cellulose and chitin. Then, the Trichoderma strains are potential candidates for being used as biocontrol agents against fungal phytopathogens whose cell wall possesses these two carbon sources. For instance, the cell wall of $F$. oxysporum consists on glucose and $\mathrm{N}$ acetyl-glucosamine, and mannose, galactose, uronic acids, and glycoproteins as well (Schoffelmeer et al., 1999; Saravanakumar et al., 2016), and the mycoparasitic contribution of the Trichoderma species is based on releasing extracellular enzymes (chitinase and cellulase) that are able to destroy the structure of the cell wall of the fungal pathogen (Infante et al., 2009; Zeilinger et al., 2016; Bunbury-Blanchette and Walker, 2019; Silva et al., 2019).

\section{Biocontrol assays of Trichoderma strains against isolates of FocR1}

Table 3 shows the inhibition percentages of eight Trichoderma strains and $T$ reesei CDBB-H-356 against five isolates of the phytopathogen FocR1. All FocR1 isolates had reduced growth due to the confrontation with the Trichoderma strains. This growth inhibition ranged from 3 to $54 \%$, and the greatest inhibition percentages were achieved by $T$. harzianum EMV6SIC5, and $T$. reesei. In particular, $T$. ressei has been described as a good antagonist to fungal pathogens like Fusarium, Phytophthora capsici, and Colletotrichum gloeosporioides (De la Cruz-Quiroz et al., 2018; Nawaz et al., 2018; Adnan et al., 2019; Saravanakumar and Wang, 2020). The achieved inhibition percentages for the five FocR1 isolates are similar to those reported by Bunbury-Blanchette $\boldsymbol{e t}$ al . (2019) who evaluated the antagonism of five native strains of Trichoderma against $F$. oxysporum f. sp. cepae, in which $T$. harzianum was the most prominent antagonist with $51 \%$ of inhibition.

It is possible to correlate the observed antagonism of T. harzianum EMV6SIC5 with its capability to degrade cellulose and chitin, as detected in our previous experimental stages with complex substrates (Figure 2). Figure 2A shows visual effects of the fungal confrontation between T. harzianum EMV6SIC5 and the five isolates of FocR1, in which the growth inhibition of the pathogen CNRFMIC17190 was of $52.2 \%$. Moreover, this antagonism is associated to the enzyme production (FPase, CMCase, chitinase) by the Trichoderma strain (Figure 2B) which was dependent on the type of substrate, at days 1, 3, 7, 9 and 14 .

In terms of fungal antagonism, the growth inhibition observed for FocR1 may be due to the expression of a mycoparasitic mechanism (Saravanakumar $\boldsymbol{e t}$ al., 2018; Silva et al., 2019) in which Trichoderma may produce hydrolytic enzymes like cellulase, chitinase, and glucanase, that act on the target fungal cell wall (Garcia-Espejo et al., 2016; Adnan et al., 2019). These enzymes are induced or regulated by the presence of simple (sugars) or complex (sugarcane bagasse, lignocellulosic residues) carbon sources used for enhancing the fungal biomass (Wang et al., 2017; De la Cruz-Quiroz et al., 2018; Weiss et al., 2020). The later denotes the relevance of assessing the capability of fungal biocontrollers for producing enzymes that contribute on the lysis of cell walls of fungal phytopathogens, which in general, are constituted by chitin, excepting for
Oomycetes such as Phytophthora whose cell wall is constituted by cellulose (Lees et al., 2012; Saravanakumar et al., 2016).

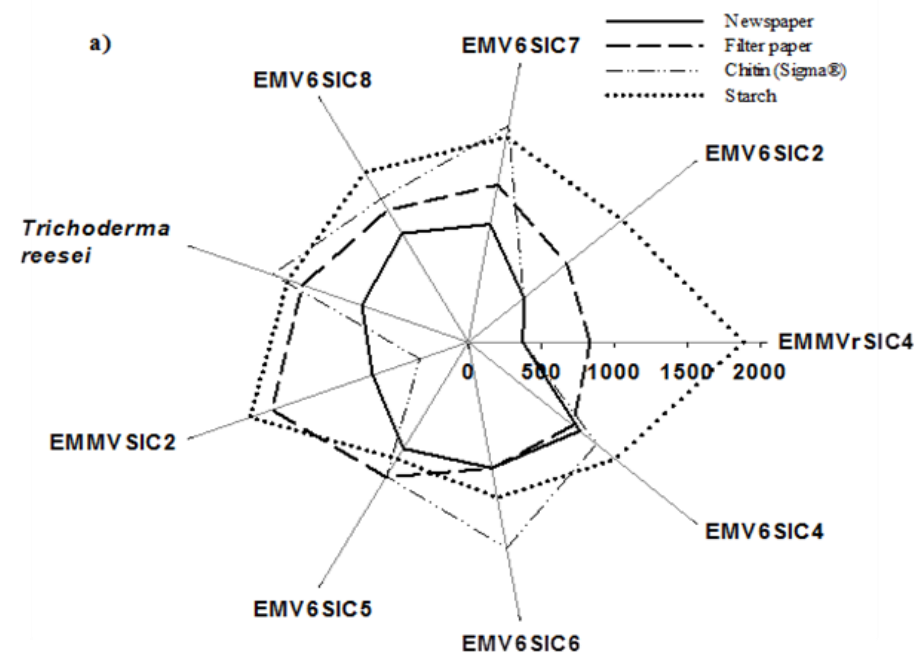

b)
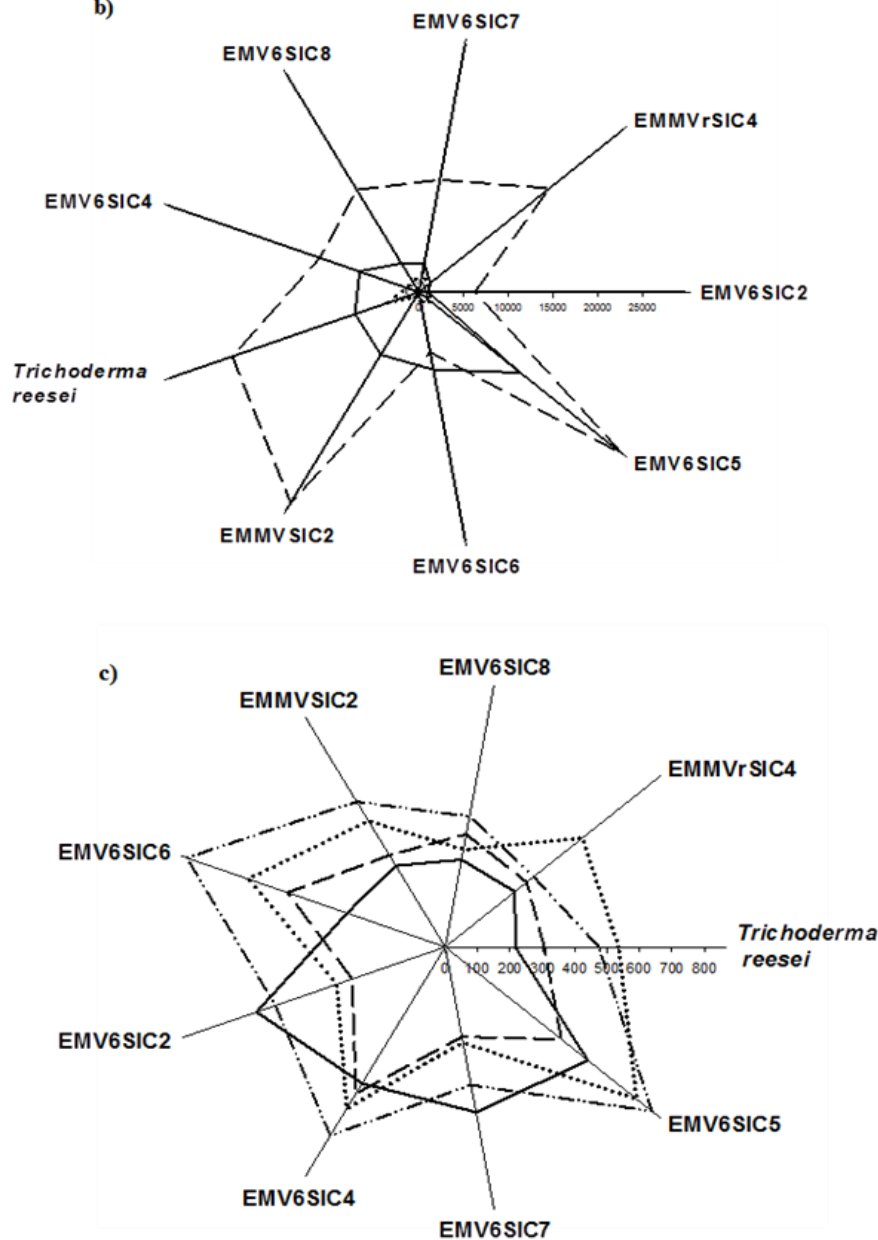

Figure 1 Radar plotting describing enzyme activities in respect to sampling time $\left(14^{\text {th }}\right.$ day), determined by nine Trichoderma fungal strains acting on four target substrates. a) Cellulase activity on filter paper (FPase) (IU/L), b) Carboxymethyl cellulase (CMCase) (IU/L), and c) Chitinase activity (IU/L).

Based on the last discussion, the cellulolytic and chitinolytic activities detected for our native Trichoderma strains, represent a good characterization for selecting prominent fungal strains directed to the biocontrol of several fungal phytopathogens as reported for Gibberella fujikuroi (Watanabe et al., 2007), Phytophthora capsici, Colletotrichum gloeosporioides (De la Cruz-Quiroz et al., 2018), and Sclerotinia sclerotiorum (Ordóñez-Valencia et al., 2015; da Silva et al., 2020), Macrophomina phaseolina, Fusarium graminearum, Botrytis cinerea (Saravanakumar and Wang, 2020), among others. 
From all native Trichoderma strains assessed in the present research, the strain $T$. harzianum EMV6SIC5 showed better biotechnological features based on its enzymatic potential, and on its antagonism to five FocR1 isolates. The late allows the possibility for developing a feasible biotechnology directed to agricultural and environmental purposes, by designing efficient bioprocesses for either producing high fungal biomass or assuring the benefits of Trichodermabased formulations.

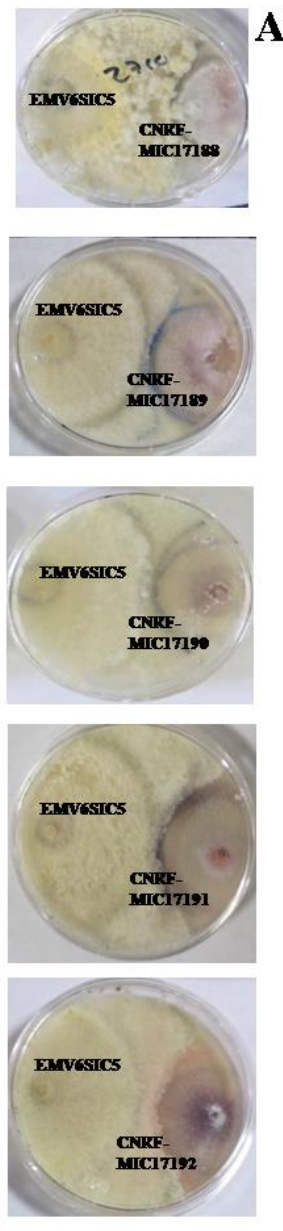

$\mathbf{A}$
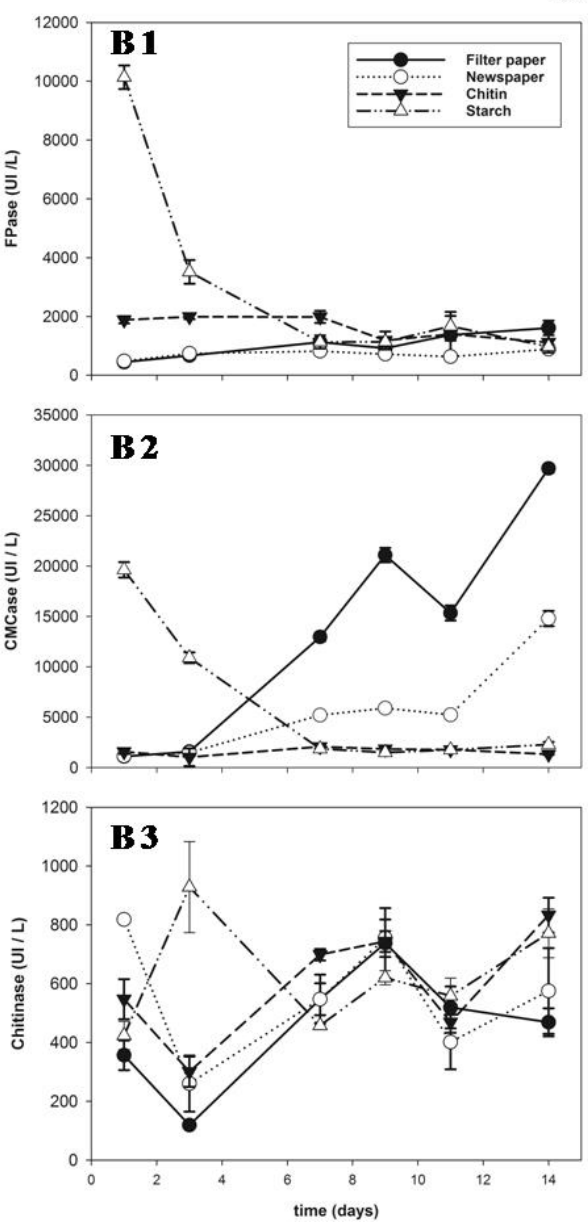

Figure 2 (A) Fungal confrontation and biocontrol activity of Trichoderma harzianum EMV6SIC5 against to five isolates of Fusarium oxysporum f.sp.cubense Race 1. (B) Cellulase (Filter paper and carboxymethyl cellulase CMCase-) and chitinase activities of T. harzianum EMV6SIC5 grown in liquid media added with four complex carbon sources, $n=3$.

\section{CONCLUSION}

All Trichoderma strains isolated from the maize rhizosphere showed positive qualitative and quantitative activity of enzymes like cellulase, chitinase and pectinase. Also, the radar plot of the Tukey multiple-comparison test showed the potential capability of these strains to produce enzymes during the degradation of filter paper, newspaper, colloidal chitin and starch as carbon sources, let us to observe the best results for T. harzianum EMV6SIC5. In addition, this fungal strain inhibited the growth of FocR 1 in about 19 to $52 \%$.

The enzyme activity and antagonism of the eight selected Trichoderma strains contributed on the degradation of complex substrates, and on the biocontrol of FocR1. Particularly, the strain T. harzianum EMV6SIC5 has special relevance for being utilized in biotechnological processes directed to agricultural purposes like the degradation of cellulose-rich organic compounds or the preparation of bioformulations directed for the biocontrol of fungal phytopathogens. Thus, Trichoderma species are susceptible for being massively propagated in bioreactors for developing agricultural inoculants.

Acknowledgments: To the National Council of Science and Technology (CONACyT-Mexico) for financial support to the postdoctoral position of D.J. HM, and to the Grant 292399 FORDECYT-CONACYT for financial support for this research. Special thanks to Dr. Randy Ortiz Castro and Dra. Ofelia Ferrera Rodríguez (Laboratorio de Microbiologia Ambiental, INECOL) for their technical support for conducting the phylogenetic analysis of Trichoderma fungal strains.

\section{REFERENCES}

Adnan, M., Islam, W., Shabbir, A., Khan, K.A., Ghramh, H.A., Huang, Z., Chen, H.Y.H. \& Lu, G.D. (2019). Plant defense against fungal pathogens by antagonistic fungi with Trichoderma in focus. Microbial Pathogenesis, 129, 7 18. https://doi.org/10.1016/j.micpath.2019.01.042

Ajijolakewu, K.A., Leh, C.P., Lee, C.K. \& Nadiah, W.A.W. (2017) Characterization of novel Trichoderma hemicellulase and its use to enhance downstream processing of lignocellulosic biomass to simple fermentable sugars. Biocatalysis and Agricultural Biotechnology, 11, 166-175. https://doi.org/10.1016/j.bcab.2017.06.005

Al-Hazmi, A.S. \& TariqJaveed, M. (2016). Effects of different inoculum densities of Trichoderma harzianum and Trichoderma viride agains Meloidogyne javanica on tomato. Saudi Journal of Biological Sciences, 23(2), 288-292. https://doi.org/10.1016/j.sjbs.2015.04.007

Argumedo-Delira, R., Alarcón, A., Ferrera-Cerrato, R. \& Peña-Cabriales, J.J. (2009). El género fúngico Trichoderma y su relación con contaminantes orgánicos e inorgánicos. Revista Internacional de Contaminación Ambiental, 25(4), 257-269.

Behera, B.C., Sethi, B.K., Mishra, R.R., Dutta, S.K. \& Thatoi, H.N. (2017), Microbial cellulases-Diversity \& biotechnology with reference to mangrove environment: A review. Journal of Genetic Engineering and Biotechnology, 15(1), 197-210. https://doi.org/10.1016/j.jgeb.2016.12.001

Bohacz, J. \& Korniłłowicz-Kowalska, T. (2020). Modification of post-industrial lignin by fungal strains of the genus Trichoderma isolated from different composting stages. Journal of Environmental Management, 266, 110573. https://doi.org/10.1016/j.jenvman.2020.110573

Bunbury-Blanchette, A.L. \& Walker, A.K. (2019). Trichoderma species show biocontrol potential in dual culture and greenhouse bioassays against Fusarium basal rot of onion. Biological Control, 130, 127-135. https://doi.org/10.1016/j.biocontrol.2018.11.007

Contina, J.B., Dandurand, L.M. \& Knudsen, G.R. (2017). Use of GFP-tagged Trichoderma harzianum as a tool to study the biological control of the potato cyst nematode Globodera pallida.Applied Soil Ecology, 115, 31-37. https://doi.org/10.1016/j.apsoil.2017.03.010

da Silva, L.R., Inglis, M.C.V., Moraes, M.C.B., Magalhães, D.M., Sifuentes, D.N., Martins, I. \& de Mello, S.C.M. (2020). Morphological and protein alterations in Sclerotinia sclerotiorum (Lib.) de Bary after exposure to volatile organic compounds of Trichoderma spp. Biological Control, 104279 https://doi.org/10.1016/j.biocontrol.2020.104279

De la Cruz-Quiroz, R., Roussos, S., Rodríguez-Herrera, R., Hernandez-Castillo D. \& Aguilar, C.N. (2018). Growth inhibition of Colletotrichum gloeosporioides and Phytophthora capsici by native Mexican Trichoderma strains. Karbala International Journal of Modern Science, 4(2), 237-243. https://doi.org/10.1016/j.kijoms.2018.03.002

de Souza, M.F., da Silva, A.S.A. \& Bon, E.P. (2018). A novel Trichoderma harzianum strain from the Amazon Forest with high cellulolytic capacity. Biocatalysis and Agricultural Biotechnology, 14, 183-188. https://doi.org/10.1016/j.bcab.2018.03.008

Delabona, P. da S., Pirota, R.D.P.B., Codima, C.A., Tremacoldi, C.R., Rodrigues, A. \& Farinas, C.S. (2012). Using Amazon forest fungi and agricultural residues as a strategy to produce cellulolytic enzymes. Biomass and Bioenergy, 37, 243 250. https://doi.org/10.1016/j.biombioe.2011.12.006

Diánez, M.F., Santos, M., Carretero, F. \& Marín, F. (2016). Trichoderma saturnisporum, a new biological control agent. Journal of the Science of Food and Agriculture, 96(6), 1934-1944. https://doi.org/10.1002/jsfa.7301

Fang, H. \& Xia, L. (2015). Cellulase production by recombinant Trichoderma reesei and its application in enzymatic hydrolysis of agricultural residues. Fuel, 143, 211-216. https://doi.org/10.1016/j.fuel.2014.11.056

Fenila, F. \& Shastri, Y. (2016). Optimal control of enzymatic hydrolysis of lignocellulosic biomass. Resource-Efficient Technologies, 2, S96-S104. https://doi.org/10.1016/j.reffit.2016.11.006

Galletti, S., Paris, R. \& Cianchetta, S. (2020). Selected isolates of Trichoderma gamsii induce different pathways of systemic resistance in maize upon Fusarium verticillioides challenge. Microbiological Research,233, 126406. https://doi.org/10.1016/j.micres.2019.126406

García-Espejo, C.N., Mamani-Mamani, M.M., Chávez-Lizárraga, G.A. \& Álvarez-Aliaga, M.T. (2016). Evaluación de la actividad enzimática del Trichoderma inhamatum (BOL-12 QD) como posible biocontrolador. Journal of the Selva Andina Research Society, 7(1), 20-32 https://doi.org/10.36610/j.jsars.2016.070100020

Gelain, L., da Cruz Pradella, J.G. \& da Costa, A.C. (2015). Mathematica modeling of enzyme production using Trichoderma harzianum $\mathrm{P} 49 \mathrm{P} 11$ and sugarcane bagasse as carbon source. Bioresource Technology, 198, 101-107. https://doi.org/10.1016/j.biortech.2015.08.148

Ghose, T.K. (1987). Measurement of cellulase activities. Pure and Applied Chemistry, 59(2), 257-268. https://doi.org/10.1351/pac198759020257

Gorai, P.S., Barman, S., Gond, S.K. \& Mandal, N.C. (2020). Trichoderma . In Amaresan, N., Kumar, M. S., Annapurna, K., Kumar, K. \& Sankaranarayanan, A. 
(Eds.). Beneficial Microbes in Agro-Ecology: Bacteria and Fungi. Academic Press. https://doi.org/10.1016/B978-0-12-823414-3.00028-9

Gruber, S. \& Seidl-Seiboth, V. (2012). Self versus non-self: fungal cell wall degradation in Trichoderma. Microbiology, 158(1), 26-34 https://doi.org/10.1099/mic.0.052613-0

Guoweia, S., Man, H., Shikai, W. \& He, C. (2011). Effect of some factors on production of cellulase by Trichoderma reesei HY07. Procedia Environmental Sciences, 8, 357-361. https://doi.org/10.1016/j.proenv.2011.10.056

Gutiérrez-Rojas, I., Moreno-Sarmiento, N. \& Montoya, D. (2015). Mecanismos y regulación de la hidrólisis enzimática de celulosa en hongos filamentosos: casos clásicos y nuevos modelos. Revista Iberoamericana de Micología, 32(1), 1-12. https://doi.org/10.1016/j.riam.2013.10.009

Hankin, L., Zucker, M. \& Sands, D.C. (1971). Improved solid medium for the detection and enumeration of pectolytic bacteria. Applied Microbiology, 22, 205 209. https://doi.org/10.1128/aem.22.2.205-209.1971

Harman, G.E., Herrera-Estrella, A.H., Horwitz, B.A. \& Lorito, M. (2012) Trichoderma-from basic biology to biotechnology. Microbiology, 158(1), 1-2 https://doi.org/10.1099/mic.0.056424-0

He, X.L., Song, C., Li, Y.Y., Wang, N., Xu, L., Han, X. \& Wei, D.S. (2018) Efficient degradation of azo dyes by a newly isolated fungus Trichoderma tomentosum under non-sterile conditions. Ecotoxicology and Environmental Safety, 150, 232-239. https://doi.org/10.1016/j.ecoenv.2017.12.043

Hernández-Melchor, D. J., Ferrera-Cerrato, R. \& Alarcón, A. (2019). Trichoderma: Importancia agrícola, biotecnológica, y sistemas de fermentación para producir biomasa y enzimas de interés industrial. Chilean Journal of Agricultural \& Animal Sciences, 35(1), 98-112. http://dx.doi.org/10.4067/S071938902019005000205

Herrera-Jiménez, E., Alarcón, A., Larsen, J., Ferrera-Cerrato, R., Cruz-Izquierdo, S. \& Ferrera-Rodríguez, M. R. (2018). Comparative effects of two indoleproducing Trichoderma strains and two exogenous phytohormones on the growth of Zea mays L., with or without tryptophan. Journal of soil science and plant nutrition, 18(1), 188-201. https://doi.org/10.4067/s0718-95162018005000704

Charoenrak, P. \& Chamswarng, C. (2016). Efficacies of wettable pellet and fresh culture of Trichoderma asperellum biocontrol products in growth promoting and reducing dirty panicles of rice. Agriculture and Natural Resources, 50 (4), 243 249. https://doi.org/10.1016/j.anres.2016.04.001

Chen, J.L., Sun, S.Z., Miao, C.P., Wu, K., Chen, Y.W., Xu, L.H., Guan, H.L. \& Zhao, L.X. (2016). Endophytic Trichoderma gamsii YIM PH30019: a promising biocontrol agent with hyperosmolar, mycoparasitism, and antagonistic activities of induced volatile organic compounds on root-rot pathogenic fungi of Panax notoginseng. Journal of Ginseng Research,40(4), 315-324 https://doi.org/10.1016/i.jgr.2015.09.006

Idris, A.S.O., Pandey, A., Rao, S. \& Sukumaran, R.K. (2017). Cellulase production through solid state tray fermentation, and its use for bioethanol from sorghum stover. Bioresource Technology, 242, 265-271. https://doi.org/10.1016/j.biortech.2017.03.092

Infante, D., Martínez, B., González, N. \& Reyes, Y. (2009). Mecanismos de acción de Trichoderma frente a hongos fitopatógenos. Revista de protección vegetal, 24(1), 14-21.

Kiriga, A.W., Haukeland, S., Kariuki, G.M., Coyne, D.L. \& Beek, N.V. (2018) Effect of Trichoderma spp. and Purpureocillium lilacinum on Meloidogyne javanica in commercial pineapple production in Kenya. Biological Control, 119 27-32. https://doi.org/10.1016/j.biocontrol.2018.01.005

Kumar, S., Stecher, G. \& Tamura, K. (2016). MEGA7: molecular evolutionary genetics analysis version 7.0 for bigger datasets. Molecular Biology and Evolution, 33(7), 1870-1874. https://doi.org/10.1093/molbev/msw054

Kumar, S., Thaku, M. \& Rani, A. (2014). Trichoderma: Mass production, formulation, quality control, delivery and its scope in commercialization in India for the management of plant diseases. African Journal of Agricultural Research, 9(53), 3838-3852.

Lees, A.K., Sullivan, L., Lynott, J.S. \& Cullen, D.W. (2012). Development of a quantitative real-time PCR assay for Phytophthora infestans and its applicability to leaf, tuber and soil samples. Plant Pathology, 61(5), 867-876. https://doi.org/10.1111/j.1365-3059.2011.02574.x

Li, C., Li, D., Feng, J., Fan, X., Chen, S., Zhang, D. \& He, R. (2019). Duckweed (Lemna minor) is a novel natural inducer of cellulase production in Trichoderma reesei.Journal of Bioscience and Bioengineering, 127(4), 486-491. https://doi.org/10.1016/j.jbiosc.2018.09.017

Libardi, N., Soccol, C.R., Góes-Neto, A., de Oliveira, J. \& de Souza Vandenberghe, L.P. (2017). Domestic wastewater as substrate for cellulase production by Trichoderma harzianum. Process Biochemistry, 57, 190-199. https://doi.org/10.1016/j.procbio.2017.03.006

López Pérez, P.A., Aguilar López, R. \& Femat, R. (2020). Control in Bioprocessing: Modeling, Estimation and the Use of Soft Sensors Part I: Overview of the Control and Monitoring of Bioprocesses and Mathematical $\begin{array}{llllll}\text { Preliminaries. John Wiley } & \text { S }\end{array}$ https://doi.org/10.1002/9781119296317.ch1

Lopez-Ramirez, N., Volke-Sepulveda, T., Gaime-Perraud, I., Saucedo-Castañeda, G. \& Favela-Torres, E. (2018). Effect of stirring on growth and cellulolytic enzymes production by Trichoderma harzianum in a novel bench-scale solid- state fermentation bioreactor. Bioresource Technology, 265, 291-298. https://doi.org/10.1016/j.biortech.2018.06.015

Marchand, C., St-Arnaud, M., Hogland, W., Bell, T.H. \& Hijri, M. (2017) Petroleum biodegradation capacity of bacteria and fungi isolated from petroleumcontaminated soil. International Biodeterioration \& Biodegradation, 116, 48-57. https://doi.org/10.1016/j.ibiod.2016.09.030

Marques, S., Matos, C.T., Gírio, F.M., Roseiro, J.C. \& Santos, J.A.L. (2017) Lactic acid production from recycled paper sludge: Process intensification by running fed-batch into a membrane-recycle bioreactor. Biochemical Engineering Journal, 120, 63-72. https://doi.org/10.1016/j.bej.2016.12.021

Miller, G.L. (1959). Use of dinitrosalysilic acid reagent for determination of reducing sugar. Analytical Chemistry, 31, 426-428 https://doi.org/10.1021/ac60147a030

Nawaz, K., Shahid, A.A., Bengyella, L., Subhani, M.N., Ali, M., Anwar, W., Iftikhara, S. \& Ali, S.W. (2018). Diversity of Trichoderma species in chili rhizosphere that promote vigor and antagonism against virulent Phytophthora $\begin{array}{llll}\text { capsici. Scientia } & \text { Horticulturae, } & 239, & 252\end{array}$ https://doi.org/10.1016/j.scienta.2018.05.048

Ordóñez-Valencia, C. (2014). Interacción de Trichoderma viride y agentes químicos antifúngicos en el crecimiento y desarrollo de Sclerotinia sclerotiorum. Tesis Doctoral. Colegio de Postgraduados. Texcoco, Estado de México. México. Ordóñez-Valencia, C., Ferrera-Cerrato, R., Quintanar-Zúñiga, R.E., Flores-Ortiz, C.M., Guzmán, G.J.M., Alarcón, A. \& García-Barradas, O. (2015) Morphological development of sclerotia by Sclerotinia sclerotiorum: a view from light and scanning electron microscopy. Annals of Microbiology, 65(2), 765-770. https://doi.org/10.1007/s13213-014-0916-X

Orea, M. D. D., Romero-Cortes, T., Lopez-Perez, P. A., Espana, V. H. P. Ramirez-Lepe, M., \& Cuervo-Parra, J. A. (2017). Current Status of Cocoa Frosty Pod Rot Caused by Moniliophthora roreri and a Phylogenetic Analysis. Plant Pathology Journal, 16(1), 41-53. https://doi.org/10.3923/ppj.2017.41.53

Porter, M. M., \& Niksiar, P. (2018). Multidimensional mechanics: Performance mapping of natural biological systems using permutated radar charts. PloS one, 13(9). https://doi.org/10.1371/journal.pone.0204309

Ranimol, G., Venugopal, T., Gopalakrishnan, S. \& Sunkar, S. (2018). Production of laccase from Trichoderma harzianum and its application in dye decolourisation. Biocatalysis and Agricultural Biotechnology, 16, 400-404. https://doi.org/10.1016/j.bcab.2018.09.003

Romero-Cortes, T., López-Pérez, P.A., Ramírez-Lepe, M. \& Cuervo-Parra, J.A. (2016). Modelado cinético del micoparasitismo por Trichoderma harzianum contra Cladosporium cladosporioides aislado de frutos de cacao (Theobroma cacao). Chilean Journal of Agricultural \& Animal Sciences (ex Agro-Ciencia), 32(1), 32-45. https://doi.org/10.4067/s0719-38902016000100004

Saary, M. J. (2008). Radar plots: a useful way for presenting multivariate health care data.Journal of Clinical Epidemiology,61(4), 311-317. https://doi.org/10.1016/j.jclinepi.2007.04.021

Saravanakumar K., Yu C., Dou K., Wang M., Li Y. \& Chen J. (2016) Synergistic effect of Trichoderma-derived antifungal metabolites and cell wal degrading enzymes on enhanced biocontrol of Fusarium oxysporum f. sp cucumerinum. Biological

Saravanakumar, K., Dou, K., Lu, Z., Wang, X., Li, Y. \& Chen, J. (2018) Enhanced biocontrol activity of cellulase from Trichoderma harzianum against Fusarium graminearum through activation of defense-related genes in maize Physiological and Molecular Plant Pathology, 103, 130-136. https://doi.org/10.1016/j.pmpp.2018.05.004

Saravanakumar, K. \& Wang, M.H. (2020). Isolation and molecular identification of Trichoderma species from wetland soil and their antagonistic activity against phytopathogens. Physiological and Molecular Plant Pathology, 109, 101458 https://doi.org/10.1016/j.pmpp.2020.101458

Sharma, A.K. \& Sharma, P. (2020). Trichoderma: Host pathogen interactions and applications. Singapore: Springer. http://dx.doi.org/10.1007/978-981-15-3321-1 Sharma, V., Salwan, R. \& Sharma, P.N. (2017). The comparative mechanistic aspects of Trichoderma and probiotics: scope for future research. Physiological and Molecular Plant Pathology, 100, 84-96. https://doi.org/10.1016/j.pmpp.2017.07.005

Schoffelmeer, E.A.M., Klis, F.M., Sietsma, J.H. \& Cornelissen, B.J.C. (1999) The Cell Wall of Fusarium oxysporum. Fungal Genetics and Biology, 27(2-3), 275-282. https://doi.org/10.1006/fgbi.1999.1153

Silva, R.N., Monteiro, V.N., Steindorff, A.S., Gomes, E.V., Noronha, E.F. \& Ulhoa, C.J. (2019). Trichoderma/pathogen/plant interaction in pre-harvest food security. Fungal https://doi.org/10.1016/j.funbio.2019.06.010

Ting, A.S.Y. \& Chai, J.Y. (2015). Chitinase and $\beta-1,3$-glucanase activities of Trichoderma harzianum in response towards pathogenic and non-pathogenic isolates: Early indications of compatibility in consortium. Biocatalysis and Agricultural Biotechnology, https://doi.org/10.1016/j.bcab.2014.10.003

Torres-De la Cruz, M., Ortiz-García, C.F., Bautista-Muñoz, C., Ramírez-Pool, J.A., Ávalos-Contreras, N., Cappello-García, S. \& De la Cruz-Pérez, A. (2015) Diversidad de Trichoderma en el agroecosistema cacao del estado de Tabasco, 
México. Revista Mexicana de Biodiversidad, 86(4), 947-961. https://doi.org/10.1016/j.rmb.2015.07.012

Vargas-Hoyos, H.A. \& Gilchrist-Ramelli, E. (2015). Producción de enzimas hidrolíticas y actividad antagónica de Trichoderma asperellum sobre dos cepas de Fusarium aisladas de cultivos de tomate (Solanum lycopersicum). Revista Mexicana de Micología, 42, 9-16.

Wang, Q., Chen, L., Yu, D., Lin, H., Shen, Q. \& Zhao, Y. (2017) Excellent waste biomass-degrading performance of Trichoderma asperellum T-1 during submerged fermentation. Science of the Total Environment, 609, 1329-1339. https://doi.org/10.1016/j.scitotenv.2017.07.212

Watanabe, S., Kumakura, K., Izawa, N., Nagayama, K., Mitachi, T., Kanamori, M., Teraoka, T. \& Arie, T. (2007). Mode of action of Trichoderma asperellum SKT-1, a biocontrol agent against Gibberella fujikuroi. Journal of Pesticide Science, 32(3), 222-228. https://doi.org/10.1584/jpestics.g06-35

Weiss, R., Eischer, A., Tadic, T., Gritsch, S. M., Ortner, M., Prall, K.,Neunteufel, E., Putz, R.F., Guebitz, G.M. \& Nyanhongo, G. S. (2020). Valorisation of slaughter house and deinking paper waste streams for the production of enzyme by Trichoderma reesei.Journal of Cleaner Production, 275, 122882. https://doi.org/10.1016/j.jclepro.2020.122882

Winogradsky, S. (1950). Microbiologie du Sols. Soil Science, 69(5), 417. https://doi.org/10.1097/00010694-195005000-00014

Zeilinger, S., Gruber, S., Bansal, R. \& Mukherjee, P.K. (2016). Secondary metabolism in Trichoderma-Chemistry meets genomics. Fungal Biology Reviews, 30(2), 74-90. https://doi.org/10.1016/j.fbr.2016.05.001 